\title{
Assessment of Hides and Skins Market in Borana, Southern Ethiopia
}

\author{
Dirriba Mengistu ${ }^{1}$ Simbone Tefera ${ }^{2}$ Tesfaye A. Tucho $(\mathrm{PhD})^{3}$ \\ 1.Holta Bee Research Center, Holota, Ethiopia \\ 3.National Beef Research Coordinator, Adami Tulu Agricultural Rese, Zeway, Ethiopia
}

\begin{abstract}
Livestock production is the mainstay of the pastoral and agro-pastoral community of Borana zone though the supply of the skin and hides from these regions is hardly addressed. As the first entry, this study was undertaken in three districts of the Borana zone with 125-sample households selected on multistage followed by random sampling method. The study was undertaken to address the existing markets and the potential demand of hides and skins in the study area and nearby markets. The assessment identified that regardless of the abundance of the livestock in the area, the supply of skin and hide in the local market is relatively low due smashed market linkage among the market actors. As a result, the potential of these commodities remains neglected though the demands for skin and hide are high in the country. Moreover, even if the pastoralists are motivated to supply skin and hide on the market, the price setting is asymmetric to the producers. The lowest intrinsic of intensive intermediaries creates a strong burden on the supply of skin and hide. Thus, it is important to create visionary market linkage with clear pricing system need timely intervention to use the potential of the skin and hind from the area.
\end{abstract}

Keywords: Borana, Hide, Marketing, Pastoralist, Price, Skin

DOI: $10.7176 / \mathrm{JMCR} / 76-01$

Publication date: February $28^{\text {th }} 2021$

\section{Introduction}

In Ethiopia, agricultural sector accounts for about $42 \%$ of GDP, more than $90 \%$ of export earnings and $85 \%$ of employment [1]. Particularly, in exports and foreign exchange earnings, livestock sector is second only to coffee in export earnings [2]. Specifically, hides and skins contribute much to the export earnings, which has a large contribution to the leather industry in the country [3]. However, with respect to its potentials, however, skin and hide contributes only marginally to the national economy [4]. The leather industry is at the forefront of the leather sector where the industry has reached an advanced stage of development and a reputation for excellence in the international market [5].

The major export contributor to the manufacturing in Ethiopia is the leather and footwear industries, which contributed $70 \%$ of the export earnings for the year 2005-2007 [5]. However, the export earnings of leather \& leather products decreased by about $1 \%$ due to a $2 \%$ fall in export volume despite $0.5 \%$ rise in international price [6]. Particularly, livestock off-take rate proves the potential of Borana zone as a potential source of skin and hide for leather industries. The off-take rate was estimated at $7 \%, 34 \%$ and $34 \%$ for cattle, sheep, and goat respectively [7], which indicates huge amount of skin and hide supply from about 1,056,040 cattle, 573,369 sheep and 868,571 goats [8].

Regardless of the livestock production, however, the supply of skin and hide from these regions is hardly addressed. Particularly, skin and hide marketing system in Borana pastoral is not yet addressed beyond some individual efforts to diversify their income from the fallen skin and hide market. Even though the area has a good ecological potential for livestock production, the supply system of skin and hide is nil.

Thus, though it was too late to study the skin and hide production and marketing system, still it is important to exploit the existing market situation in the pastoral area. With these regards, the study addressed the existing marketing systems of raw hides and skin in Borana pastoral area.

\section{Methodology}

Borana zone is located at the southern tips of Ethiopia, which share a single borderline with Kenya. The topography of the zone is categorized as $10 \%$ highland, $20 \%$ temperate and $70 \%$ lowland with the average temperature range between $18-280 \mathrm{c}^{0}$ [9] with the average annual rainfalls of $450-650 \mathrm{~mm}$.

In fact, to draw the final sample, the study followed two-stage-sampling methods followed by a simple random sampling procedure. At the beginning, the districts in the zone and PAs in the districts were stratified based on the potential of the livestock production and simple randomly from the selected PAs ${ }^{1}$ with a proportionally distributions based on the number of population and area coverage. In addition, representatives of available local collectors of raw hides and skins in the zone were interviewed. Finally, three districts were selected from Borana zone where two PAs were selected from each selected district to draw 125 households for final interview.

\footnotetext{
${ }^{1}$ Peasant Association: it is the last administration unit in Ethiopia
} 
As tools for data collection, checklists and questionnaires were used to collect information from producers and local traders. Relevant secondary data were also obtained from the districts and zonal Pastoral Development Offices. Moreover, both informal and formal survey methods were conducted to collect primary information from producers, traders, and collectors. Generally, the study used descriptive statistics to examine and explain basic characteristics of the market system of raw hide and raw skin in the study area.

\section{Results and Discussion}

Pastoralists never slaughter their livestock for purposes of skin and hide, but for the meat consumption. From the survey result, $43 \%, 59 \%$ and $32 \%$ of the respondents reported, as they have been slaughtered sheep, goat, and cattle respectively (Table 1). However, the supply of skin and hide in the local market is relatively null. Besides lack of buyers and lower price, the motives to supply are nonetheless besides poor awareness in its marketability. Though various reasons aligned behind the low demands of skin and hide (e.g. conventional taping and burning), it should be noticed as a loss to the pastoral economy.

Table 1. Skin and hide production and selling

\begin{tabular}{|c|c|c|c|c|c|c|}
\hline \multirow{2}{*}{ Description } & & \multicolumn{2}{|c|}{ sex of respondent } & & \multicolumn{2}{|c|}{ Total } \\
\hline & & Male & Female & & $\mathrm{N}$ & $\%$ \\
\hline \multirow{3}{*}{ Slaughtered } & Goat & 23 & 51 & & 74 & $59 \%$ \\
\hline & Sheep & 16 & 33 & & 49 & $43 \%$ \\
\hline & Cattle & 8 & 28 & & 36 & $32 \%$ \\
\hline \multirow{2}{*}{ Sell skin and hide } & Yes & & & 2 & 5 & $4 \%$ \\
\hline & No & & & 42 & 62 & $55 \%$ \\
\hline
\end{tabular}

Source: Own survey, 2018

Even though the trends of skin and hide production is increasing, the product has been used for conventional purpose or thrown away in the area. Moreover, the tremendous potential for skin and hide from Borana pastoralists is also not ignorable due to higher livestock off-take. In any case, only $4 \%$ of the respondent households can supply one or more skin and hide to the village markets, where on average, households slaughter 2-sheep and 2-goats per year with a range of 1-7 sheep and 1-6 goats (Table 1).

In current situation, the price of skin and hide is very low (Table 2), which provides lower incentives to the sellers, particularly for those producers traveling from a long distance to sell a single skin and hide. If the supply of skin and hide is sophisticated, its price should be at equitable with the cost of travelling to the celling center, $12 \mathrm{~km}$ in the case of this study area.

Table 2. Socio-economics characteristics

\begin{tabular}{lllllll}
\hline \multicolumn{2}{l}{ Variables } & N & Minimum & Maximum & Mean & Std. Deviation \\
\hline \multicolumn{2}{l}{ Age of respondents' } & 106 & 18 & 100 & 37.96 & 16.08 \\
\hline \multicolumn{2}{l}{ Total Family size } & 111 & 1 & 90 & 8.27 & 8.43 \\
\hline \multicolumn{2}{l}{ Distance from nearest market } & 85 & 1 & 30 & 11.68 & 5.92 \\
\hline \multirow{3}{*}{ Number owned } & Cattle & 113 & 1 & 30 & 5.43 & 5.31 \\
& Goats & 112 & 1 & 100 & 10.26 & 12.52 \\
& Sheep & 107 & 1 & 25 & 4.71 & 5.50 \\
\hline \multirow{2}{*}{$\begin{array}{l}\text { Number } \\
\text { slaughtered per }\end{array}$} & Sheep & 28 & 1 & 7 & 2.18 & 1.52 \\
annual & Goats & 35 & 1 & 6 & 2.34 & 1.39 \\
\hline Current price of goat skin (ETB) & 4 & 5 & 4 & 1.67 & 1.00 \\
\hline Number of Goat skin sold (ETB) & 3 & 2 & 20 & 10.00 & 7.07 \\
\hline
\end{tabular}

Similarly, the CSA data displayed that the number of goats and sheep off-take through slaughtering had been changing annual by 4\% and 4\% respectively between 2007-2013 in Borana zone, which hints the growth of skin and hide potential. Even though trends show growth in the production of skin and hide, the supply to the market remains very poor due to no or low market access. 


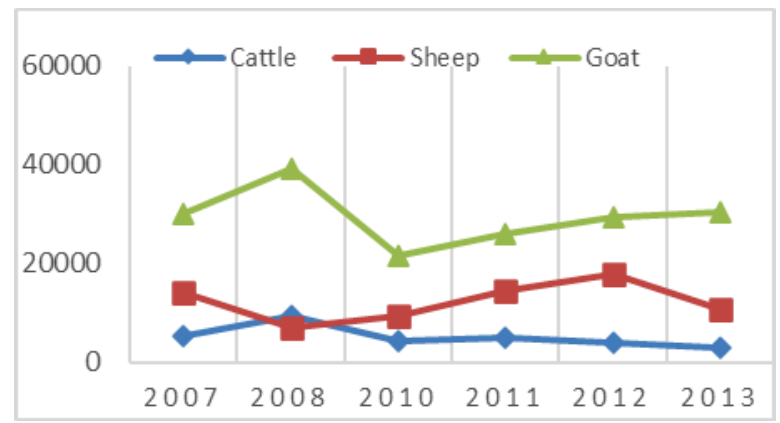

Figure 1. Number of livestock slaughtered in Borana from 2007-2013 (Source: CSA)

Moreover, still skin and hide have been exported to different countries from Ethiopia that have been generating foreign currency. However, the loss of skin and hide in pastoral area is the loss to the economy of the county, Ethiopia, in general.

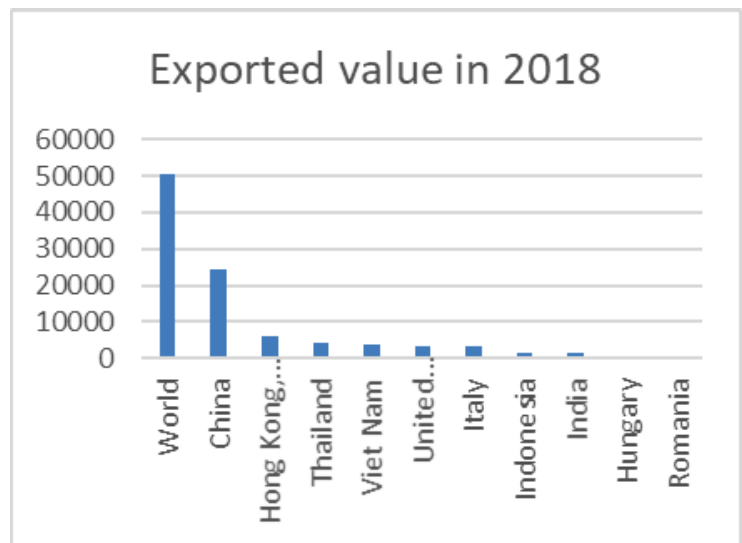

Figure 2. Major Country importing Skin and hide from Ethiopia (International trade center based on ERCA data)

In this study, the price of skin and hide ranges between 5 - 30 ETB (Table 2), which even unable to cover the transportation cost to the market place. This demands conducive market creation besides the clear market information that needs equal effort to encourage the supply of skin and hide. Otherwise, the current price is hardily encouraging the supply of skin and hide.

\section{Challenges of raw hide and skin marketing}

The supply of skin and hide from these areas is hardly appreciated regardless of the higher meat consumption habit of the community. Particularly, lack of market (buyers) and low-price offer are among the very critical challenges. As a result, most of the respondents were hardily worrying about the supply of skin and hide in the local market due its inadequate reward. On the other hand, even though the pastoralists are supplying, lack of market and collection center is another bottleneck.

During the field survey, the collectors reported that the potential of traders in the central market poorly absorbs the market in the pastoral area. On the other hand, traders complained that the marketing system of skin and hide is not stable, which affects the consistency of supply to the central market. At the same time, they were suffering due to lack of conducive infrastructure such as storage facility. As a result, traders and collectors are buying skin and hide from the pastoralists based on the demands and market arrangement from the central market; otherwise, they do not purchase. Similarly, the price decision is top down, where the local traders were hardly aware of the price of hides and skins in the central market. However, traders (buyers) themselves determine the price of skin and hide in favor of their profit.

\section{Conclusion and Recommendation}

In Ethiopia, hides and skins contribute much to the export earnings from livestock sector particularly, in the leather industry. However, the supply of skins and hides from pastoral regions is hardly addressed, though livestock production is their mainstay. Particularly, skin and hide marketing system in Borana zone is not yet addressed beyond the individual efforts to diversify their income from the poor market.

The survey result showed that though there is high potential for skin and hide, the supply of skin and hide in the local market is very low. As a result, the potential of these commodities in the area remains neglected even though the demands of skin and hide is higher in the country. Thus, creating a strong market linkage with the central market could create many opportunities to fill the unmated demand for the raw skin and hide as a country. Besides, this effort has a double benefit to boost the pastoral economy either by increasing income of the pastoral 
household or at the same time creates employment opportunities for the graduate in the pastoral area.

However, further investigation for poor linkage between central market and local suppliers is very urgent. Additionally, the local government should build a local synergy by organizing, training, financing, and linking the local production potential to the central market. However, it demands further investigation on the quality analysis, its financial reward and potential leverage point.

\section{Acknowledgement}

We acknowledge the Ethiopian Institute of Agricultural Research (EIAR) for financing this work. However, the concerns in this paper remain to the responsibilities of the authors.

\section{References}

[1] CSA, "Key Findings of the 2017/2018 (2010 E.C) Agricultural Sample Surveys. The Federal Democratic Republic of Ethiopia Central Statistical Agency (CSA), Country Summary.," Ethiopia Central Statistical Agency, Addis Ababa, Ethiopia, 2018.

[2] H. Ayalew, E. Tamiru and Y. Nega , "Hide and skin quality factors and marketing systems in Gondar town, Ethiopia," J. Anim. Feed Res, vol. 8, no. 5, pp. 120-125, 2018.

[3] M. Girma, "Opportunities and challenges of hides and skins trade in Ethiopia," in Opportunities and challenges of hides and skins trade in Ethiopia, Addis Ababa, Ethiopia, 2003.

[4] B. Alemnesh, T. Getachew and J. Tariku, "Assessment of quality and marketing of hide and skin in Adamitulu Jidokombolcha and Bora Woreda in East Shewa Zone of Oromia Regional State, Ethiopia," International Journal of Livestock Production, vol. 9, no. 10, pp. 269-279, 2018.

[5] MoTI, "A Strategic Action Plan for the Development of the Ethiopian Leather and Leather Products Industry: Integrated Plan for Ethiopia, Volume 1," Minstry of Trade and Industry (MoTI) of Ethiopia, Addis Ababa, Ethiopia, 2004.

[6] NBE, "2016/17 Annual Report Annual Report," National Bank of Ethiopia, Addis Ababa, Ethiopia, 2017.

[7] ICPALD, "The Contribution of Livestock to the Ethiopian Economy. , Policy Brief No: ICPALD 5/CLE/8/2013.," IGAD Center for Pastoral Areas \& Livestock Development (ICPALD), Addis Ababa, 2013.

[8] CSA, "Agricultural Sample Survey, Volume II," Central Statistical Agency (CSA), Addis Ababa, 2017.

[9] A. Ibrahim, HIV/AIDS, gender and reproductive health promotion: the roles of traditional institutions among the Borana Oromo, southern Ethiopia: contemporary issues in Borana, and the 38th Gumii Gaayoo Assembly,, Finfinne [Addis Ababa]: https://searchworks.stanford.edu/view/6750623, 2005. 